\title{
White collar crime, consumers and victimization
}

\author{
Hazel Croall
}

Published online: 5 November 2008

(C) Springer Science + Business Media B.V. 2008

\begin{abstract}
Consumers have long been recognized as one of the major groups of victims of white collar and corporate crime, although many of the activities which harm them are not widely regarded as 'crime'. They tend to attract less publicity, and have been subject to less academic research, particularly in comparison with major financial frauds or cases involving mass harms. Moreover, there has been a tendency to view consumers as a relatively undifferentiated group, all of whom are likely to be victimized. This article identifies a wide range of crimes which affect consumers and explores some of the characteristics of victims and offenders, arguing that while all consumers are at risk, the impact of consumer crime, like other forms of crime, reflects wider patterns of structural inequality and falls most severely on the most disadvantaged.
\end{abstract}

Consumers are generally regarded as one of the main groups victimized by white collar and corporate crime and all consumers are subject to fraud, safety and health threats and deception from the production and sale of consumer goods and services. Serious as these harms are, many are not widely regarded as "crime." While all consumers, irrespective of gender, age or socio economic status, are affected, it can be argued that victimization reflects wider social inequalities [20-22]. This paper will start by identifying what kinds of crimes consumers are victims of before briefly looking at the characteristics of offences, offenders and victims. It will then outline the impact of selected forms of crime before exploring in more depth the way in which victimization is related to structural inequalities.

H. Croall $(\bowtie)$

Law Division, School of Law and Social Sciences, Glasgow Caledonian University,

Cowcaddens Road, Glasgow G4 OBA, UK

e-mail: h.croall@gcal.ac.uk 


\section{What are crimes against consumers?}

There are few definitions of this vast area of offending. Legal and administrative definitions, such as that of the British Department of Trade and Industry (DTI), refer to 'consumer protection law' which encompasses the quality, safety, content and descriptions of goods and services, including selling practices such as doorstep sales. It defines a 'core area' which excludes food, public utilities, credit and financial services, which many others include, but nonetheless involves approximately 65 separate Acts of Parliament [27]. This paper will include food and utilities but will exclude financial services, price fixing, consumer credit and the wider provision of health services, largely for reasons of space.

Crimes involving consumers have tended to receive less public or academic attention than other areas of white-collar and corporate crime such as financial frauds or occupational health and safety. In part this may be because they are less likely to involve high profile cases involving mass deaths or major financial losses. Many offences, such as the sale of out of date food or short weight goods, are often seen as trivial matters. The long term health of consumers is also endangered by the use, in foods and other consumer products, of a vast range of chemicals and other substances which, while associated with long term health risks, do not result in immediate harm. While there is growing public concern about a number of food and consumer issues, these have a lower political and governmental profile, in the UK at any rate, than occupational health and safety or the environment [28].

\section{The characteristics of crimes against consumers:}

Crimes with consumer victims display many of the characteristics associated with white collar crime ${ }^{1}$. They are often invisible, as consumers are unaware of any harm and cannot check the ingredients of processed food or other products. Enforcement involves regulatory agencies rather than the police, constrained resources restrict the number of inspections and only a small number of detected cases end up being publicly prosecuted ${ }^{2}$. Enforcement is less high profile than other regulatory areas [27]. This makes assessing the number and nature of offences particularly difficult and there are few official statistics or victim surveys on which to base estimates or guesstimates $^{3}$.

As for other white-collar crimes, considerable ambiguity surrounds the 'criminality' of activities [4, 20, 57], and the line between 'criminal', 'illegal' and 'legal' is narrow and contested. What is, for example, the distinction between a legal 'puff', a 'misleading' description, a 'con' and a fraud ${ }^{4}$ ? At what point do descriptions deceive

\footnotetext{
${ }^{1}$ see for example, [20, 57]

2 see for example, [20, 57]

${ }^{3}$ see for example, [21, 22, 72]

${ }^{4}$ [76] discusses this point as have many classic white collar crime theorists for example [37]
} 
consumers? Many inherently deceptive marketing practices are not regulated by criminal law but by a range of administrative codes and advertising standards. Even where consumers are harmed by activities which clearly breach criminally enforced regulations they are not widely perceived of as 'criminal'. The discourse of consumer protection contains phrases such as consumer 'detriment', 'loss of welfare', 'misleading' descriptions, 'misselling' or 'marketing malpractice' rather than crime, theft, fraud or dishonesty. Regulators refer to compliance rather than to policing or punishment. In common with the approach of other criminologists ${ }^{5}$, this paper will explore activities which lie outside the scope of criminal law but involve forms of regulation which result in penalties along with activities which have been subject to campaigns for criminalization and regulation.

\section{Who are the offenders?}

The relatively low profile of crimes involving consumers may also be associated with the assumption that they mainly involve small scale 'rogues' and 'cowboys', whose businesses lie on the fringes of legality and illegality, rather than large corporations. While these groups may well dominate prosecutions [16] major corporations are involved, although their offences are generally portrayed as minor, trivial matters when placed in the context of the vast scope of their operations [15]. As Sutherland found [76] many are repeat offenders, with, in Britain, some large supermarkets such as TESCO and ASDA, part of the Wallmart chain, amassing a string of convictions for different offences. Advertisements by 'household names' such as McDonald's and Estee Lauder have been criticized by the British Advertising Standards Authority (ASA) ${ }^{6}$. Large corporations are also better able to resist further regulation, can use the existence of compliance systems to avoid prosecution and can employ their resources to sidestep the 'letter' of the law while engaging in activities which clearly breach its spirit [16]. Large food manufacturers, for example, are generally opposed to extensions of food labeling laws. The impact of criminalization falls more severely on smaller businesses whose activities can more readily be defined as 'unscrupulous' or dishonest. Consumers can also be harmed by the activities of 'organized' criminals involved in the manufacture, distribution and sale of illegal products such as contraband cigarettes, counterfeit products or 'meat laundering' [20, 21, 44, 68].

\section{What is the nature of victimisation?}

Consumers are subject to 'repeat victimization'. Indeed, 'virtually all of us have been ripped off at one time or another - often again and again, sometimes without

\footnotetext{
${ }^{5}$ see for example [20, 72]

${ }^{6}$ see specific cases below
} 
ever knowing it' ([67]: 31). Physical and economic harms are involved. Consumers can be killed by food poisoning, injured by unsafe products, defrauded by unscrupulous sales persons and are daily deceived by descriptions of goods and services. At home they are subject to a range of doorstep sellers, telemarketers and computer sales, to fraud and shoddy work by 'cowboy' builders, to the hazards posed by furniture, toys or utilities and to longer term threats posed by chemicals in food, cosmetics, household cleaners, carpets and computers ${ }^{7}$. In the garage they face being defrauded by sales personnel or mechanics, in the shops they buy goods and foods whose contents they may only be dimly aware of and which are not clearly stated, and when travelling they face higher fares as a result of price fixing or are endangered by unsafe practices ${ }^{8}$. In Britain, for example, many fatalities have been involved in rail crashes associated with management failures ${ }^{9}$. Their long term health is threatened by inadequately tested and undeclared chemicals and other substances in foods and consumer products and they pay more for goods and services as a result of misleading selling and marketing practices.

Consumers are nonetheless not widely perceived, nor do they perceive themselves to be, major victims of 'crime'. This is associated with key features of white collar crime victimization [21, 22, 47]. It is diffuse [76] in that large numbers of consumers are only minimally harmed by offences involving a small deficiency in a large number of goods. As seen above, consumers are often unaware of any harm and do not have the knowledge to assess, for example, the quality of work which has been done to their car or house. In yet other cases the harm, if recognized, is regarded as very trivial and not worth the effort of complaining about. Consumers may also blame themselves for being 'taken in' by clever sales practices or for not being sufficiently informed. The ideology of caveat emptor, let the buyer beware, still arguably affects consumers and governments are keen to encourage consumers to be well informed. Moreover, it has already been seen that the social construction of crime tends to exclude many offences. While consumers may be annoyed or irritated, they may not complain to regulatory authorities resulting in many offences not being 'counted' as such.

This means that the researcher must move beyond conventional criminological research and sources such as official crime statistics and victim surveys. Although not represented as 'crime' many relevant activities are regarded as 'issues' or 'scandals' and a wide variety of information is available from the mass media, investigative journalism, regulatory agencies, Government departments and a range of consumer and other interest groups [22]. This paper is based on these kinds of sources which, while not as systematic as victim surveys, do provide a vast volume of information. A brief snapshot of selected offences and their impact follows, starting with those involving food and moving on to other consumer goods and services.

\footnotetext{
${ }^{7}$ Merseyside HAZARDS and Environmental centre Fact sheets 5, 9, 10 and 11 available from Merseyside HAZARDS and Environmental Centre Toxteth Town Hall Liverpool

8 for a detailed account of sites of victimization see [17, 21, 22]

${ }^{9}$ See for example, [20, 72]
} 


\section{'Food crime' [23]}

The manufacture and sale of food involves a wide range of offences causing a variety of harms and involving deceptive selling practices, although the borderline between the legal and illegal is very narrow. Examples include:

\section{Food poisoning}

Food poisoning, a major source of death and illness for consumers, is associated with breaches of criminally enforced hygiene regulations. In central Scotland, 21 elderly people died after consuming meat supplied by a butcher who was subsequently convicted [18, 20, 24]. In Japan, 13,000 people felt ill and 200 suffered illness after consuming contaminated milk products [66]. A survey by the British Food Standards Agency (FSA) and Which?, the magazine of the British Consumers' Association, found that $13 \%$ had experienced food poisoning in the previous year. Prosecutions are rare, with the same survey reporting that only $0.5 \%$ of the $42 \%$ of UK food businesses, found in 2001 to have failed to fully comply with food law, were prosecuted [84].

Food adulteration and food frauds

Adulterating food with water is a common practice in much of today's modern food processing. It is injected into chickens to give them 'bulk' and meat products in Britain's major supermarkets have been found to contain water. TESCO was convicted in 2002 for selling 'tender select pork leg' without declaring added water, glucose, syrup and salt on the outer label. The company claimed that the water is added to improve eating quality. Adding water up to a certain proportion is 'legal' (although it must be declared on the label) and the FSA, while agreeing that it is 'completely unacceptable for the consumer to be paying for water' saw no reason to ban the practice [45].

The practice of 'food laundering' also lies on the fringes of the law. In a widely reported case, Dutch food processors imported cheap frozen chicken from Thailand and Brazil, much of it salted to avoid European Union tariffs on fresh meat. The meat was defrosted, injected with water and additives and tumbled into giant machines. It was refrozen and passed on to food manufacturers and caterers. Pork proteins have also been found in chicken, some of it labelled 'halal' [44]. Other British cases of 'meat laundering' have involved groups described as criminal 'gangs'. A defendant known as 'Maggot Pete' was convicted for doctoring unfit meat which could have carried hepatitis and E.coli and selling it to hospitals, schools and local supermarkets $[44,75]$.

The contents of food

Many concerns have been raised about the 'legalized adulteration' [44] of food by additives and other substances which are not fully declared on labels. Modern food processing relies on the use of Mechanically Recovered Meat (MRM), in which parts of the animal not normally associated with consumption are used, and many 
foods also contain genetically modified (GM) ingredients or starch, hard fats and hydrogenated oils [44]. Additives, used for cosmetic reasons and to replace more expensive 'natural' ingredients, are often undeclared and untested. Flavourings are not, for example, tested in the UK and do not have to be individually declared on the label [44, 51]. An FSA investigation found that most processed foods contain elements of GM whether or not declared on the label [85] and one study found that around $80 \%$ of tested products, including vegetarian sausage mix and organic burger meat labeled 'GM free' or 'organic', contained genetically modified soya [81]. Other food products contain low proportions of 'natural' ingredients. One pack of 'chicken nuggets', for example, was found to contain only $16 \%$ meat, $30 \%$ less than indicated on the label [44].

\section{Misleading indications}

Food labels can also mislead consumers, particularly those indicating ingredients in percentages and those written in small print [83]. Advertisements and labels can mislead consumers about, for example, nutrient or fat contents. A notorious example was the widely used claim that food products are ' $90 \%$ fat free', which although accurate, is misleading as a $10 \%$ fat content is considered 'high fat'. Other widely used terms such as 'light' or 'extra light' have little meaning [90]. A number of investigations have also revealed that many products claiming to be 'low-fat' or 'nutritious' actually contain high amounts of salt, fat or sugar [89]. A Which? report on 'cereal offenders' found that $85 \%$ of 100 cereal products, including most of those marketed for children, contained 'a lot' of sugar, $40 \%$ contained 'a lot' of salt, and many contained hydrogenated oils, (associated with trans fats) [86]. Another investigation revealed that the ingredients of $17 \%$ of products tested fell outside legally 'acceptable' error margins with many containing more calories and fat than indicated on the label [90]. Specific health claims are also regulated. ASDA (part of the Wallmart chain) was recently convicted in Britain for claiming that the 'antioxidant properties' in mangoes helped to fight cancer ${ }^{10}$.

\section{Misleading descriptions}

Other terms can be misleading. The British FSA found many breaches of guidelines for the use of terms such as 'fresh', 'natural', 'pure', 'traditional', 'original', 'authentic' and 'home-made'. Around three quarters of "farmhouse" products, which should be made in a house on a farm, were produced in industrial premises. "Traditional" foods should be made from recipes, ingredients and cooking methods which have "existed for a significant period", but TESCO was criticised for labelling as 'traditional' an 'Irish Wheaten Loaf' which was baked in store and contained flour treatment agents that were "unlikely to be part of the Irish tradition". The label "traditional-style" was said to be "meaningless", and the term "homemade" was also

${ }^{10}$ Birmingham Post 'Asda Fined $£ 5,000$ after claiming anti cancer properties of its mangoes' October 27 2004 p7 
widely misused to describe goods originating outside 'domestic facilities' and produced on a large scale $[69,80]$.

Misleading pictures

Pictorial images are also 'descriptions'. A Which? report lists a number of 'photographic tricks' such as blow torching food to give a 'grilled' or barbequed look, showing a pie full of ingredients when in reality it may not be 'full', and misleading indications of portions - in some cases, small plates are used to indicate a 'full plate'. The British Independent Television Commission ruled against a McDonald's advertisement in which all the fillings of a burger were pulled to the front making it look fuller than it really was [87].

Food packaging

The use of larger than required packages, once described as selling fresh air [14], is also deceptive. Practices include wrapping small numbers of biscuits inside small packs and putting them together in one large pack along with using large packages for smaller amounts of food. Suppliers are said to capitalise on consumer behaviour as research indicates that consumers often ignore labels indicating quantity and judge the amount of goods by their look or feel [90].

\section{Consumer goods and services}

A similar set of issues are involved in other consumer goods and services and areas dominating consumer complaints and prosecutions can be identified as particular problems. In the US for example, the top ten consumer complaints of 2002 involved automobile sales, home improvements, automotive repairs, credit, advertising and telemarketing, collections and billing practices, household goods, the Internet and e commerce, telecommunications and real estate [34]. In Britain, major sources of complaints and prosecutions include home maintenance repairs and improvements, car sales, repairs and servicing, telecommunications services, the provision of utilities, financial services and doorstep selling [9]. The contents and safety of cosmetics, cosmetic surgery and other household items are also major concerns and the following sections include a selection of these areas.

\section{Consumer safety:}

It is difficult to establish the extent to which consumers are injured or killed by consumer products as not all cases are attributed to products or result in criminal investigation or prosecution [63]. Estimates of the injuries and deaths caused by unsafe products in Britain vary. A DTI investigation of 11,998 home accidents for example found that $1.6 \%$ of fatalities, $0.4 \%$ of serious injuries and $0.6 \%$ of minor injuries were attributable to product fault mostly due to poor servicing or maintenance of gas and electrical heating equipment [26]. A Which? report on product recalls claims that each year, seven people are killed by unrecalled unsafe 
products and 35 new products are dangerous but not recalled [88]. The Chief Product Safety Adviser for Britain's Royal Society for the Prevention of Accidents (ROSPA) argues that a decline in the resources available for investigating product safety has led to an increasing risk of injuries and unsafe consumer products and, he estimates, contributed to 2.8 million domestic accidents in 1999 . He also cites research estimating that around 750,000 injuries each year in the UK involve poorly designed or unsafe products [63]. Counterfeit goods can also be dangerous, with consumers having been burned by fake perfume and poisoned by counterfeit vodka [22].

\section{Cosmetics}

In the UK, the cosmetic and toiletries industry, worth $£ 6$ billion, uses up to 9,000 chemicals, whose long term effects have yet to be established [7]. These include carcinogenic substances such as coal tar, found in eye shadow and artificial colourings, nitrosamines, found in liquid foundations and used as wetting agents in facial cleaners, body washes and shampoos, and arylamines, present in hair dyes and linked to bladder cancer [94]. While business representatives claim that chemicals are used in tiny amounts and pose no health threat, others are concerned about the 'cocktail' effect of combinations of chemicals. Some products such as moisturisers are designed to be absorbed and lipsticks are swallowed [94].

Cosmetic surgery can cause injury and illness and clients may not be fully aware of risks. Silicone breast implants for example caused many illnesses and, although not prosecuted, one company, Dow Corning, was found to have acted with 'fraud, malice and oppression' $[19,33]$. Botox treatments have also caused problems with four people having been paralysed in Florida in 2004 after being injected with unlicensed botulinum toxin [38]. In Britain new regulations followed widespread concerns about beauty treatments. Many private clinics failed to carry out basic checks on surgeons [49], and 'Botox' or 'cosmetic' 'cowboys' were found to have obtained illegal supplies on the Internet for use in unlicensed parlours or Botox parties $^{11}$. Cosmetic fillers have also been linked to the transmission of CJD, hepatitis and blood or tissue borne viruses [11]. Clinics have also been found to recommend unnecessary work or provide wrong or inadequate information [43].

A range of 'meaningless' terms such as 'natural', 'organic' or 'dermatologist approved' are used to describe cosmetics. The widely used term 'hypoallergenic' simply means that the product is unlikely to cause an allergic reaction and 'unscented' means that the product has no noticeable odour although fragrance, in the form of 'parfum' which can include up to 200 undeclared ingredients, may be added to mask the smell of other ingredients [7]. A narrow line divides acceptable 'puffery' from misleading descriptions. It is for example legal 'puffery' for cosmetic manufacturers to claim that products enhance beauty or even 'perfection' however the FDA has warned against 'aggressive boasting' about anti ageing creams - if they claim for example that a product affects the skin's structure or function they would be considered as drugs [8]. Britain's ASA has ruled against Estee Lauder's claims that products reduce the 'appearance' of cellulite which could readily be taken to

11 [39], Daily Mail 'Health chiefs crack down on the cosmetic cowboys', Jan 29, p. 13 
claim an actual reduction, and also against the claim for Pantene Pro-v that the shampoo makes hair up to ten times stronger as this could be taken literally as a claim that it actually repairs hair [48]. Cosmetics and perfumes are often lavishly packaged and a practice associated with the sale of cosmetics is the use of 'double walled jars' [19]. It has also been estimated that as much as $50 \%$ of the cost of a bottle of perfume can be taken up by packaging and advertising [31].

\section{Home repairs and maintenance}

As seen above, home repairs and maintenance feature highly amongst consumer complaints and a number of British sources indicate the impact of this problem. In North Wales a local 'rapid response team' was set up to tackle cases of overpricing involving annual gains of around $£ 200,000$ [62]. One insurance broker estimated that over a 5 year period, nearly 5 million people in Britain were victimized by 'cowboy' traders. Victims reported sleepless nights along with feelings that their homes had been abused and some had to take time off work. Plumbers, builders, roofers and plasterers were the main offenders [59]. A survey by British Gas in Wales estimated that more than 300,000 home owners were affected with more than a third interviewed reporting having been 'ripped off' [10]. In another investigation Trading Standards officers were described as being 'appalled' by almost one quarter of 44 tradesmen invited to carry out simple jobs in a 'house of horrors' which they set up [64].

\section{Car repairs and servicing}

The most celebrated case involving the safety of motor cars was the Ford Pinto, which caused several deaths and severe burn injuries before being withdrawn. The design fault was known although it was decided to carry on producing the car [65]. Car repairs and servicing is, as seen above, another major area of consumer concern [67]. In the US the Federal Trade Commission has estimated that as much as $30 \%$ of money spent is for unnecessary repairs and that auto repair shops are daily cheating Americans out of $\$ 57$ million. In one study nearly $10 \%$ of 338 sites recommended purchasing a new battery although the battery used was perfectly functioning ${ }^{12}$.

In Britain, a similar 'mystery shopping exercise' involving car servicing and repair was carried out in 2002. Trading Standards Officers rated over half the garages they visited as poor or very poor. $17 \%$ carried out unnecessary work, $40 \%$ missed or did not replace at least one item on the service schedule, $86 \%$ missed at least one fault and $43 \%$ provided no accurate quotes. $28 \%$ of fast fit centres were rated poor or very poor, with around one third unjustifiably recommending brake components and others unjustifiably recommending tyre replacements [30]. The British National Consumer Council (NCC) has calculated that the individual consumer typically loses $£ 235$ for each unsatisfactory repair or service and the DTI has estimated that consumers could lose up to $£ 4$ billion per annum [53]. Other problems have included the safety of second hand cars, in particular the practice of reconstructing vehicles, known as 'cut and shuts' from cars which have been

\footnotetext{
${ }^{12}$ Jesilow (1986) cited in [67]
} 
damaged. These were estimated to be a factor in up to 360 deaths and 4,300 injuries in the period surveyed [22]. So called car 'clocking', turning back the odometer to reduce its apparent mileage, was also estimated to cost consumers as much as $£ 100$ million in $1990^{13}$.

\section{Utilities:}

Utilities such as gas, electricity and water have been associated with a number of offences. In Scotland, a family of four were killed in a gas explosion in their house in December 1999 and the main gas supplier TRANSCO was subsequently given a 'record' fine of $£ 15$ million for failing to maintain the supply pipes and to keep adequate records [1, 21, 22]. Consumers have also been killed and made ill by inadequately maintained central heating systems [21]. Electrical goods can also injure consumers, particularly cheap imported goods ${ }^{14}$.

In Britain, power companies have been found to engage in an assortment of 'unscrupulous sales techniques' and 'high pressure selling' when attempting to persuade customers to change suppliers, particularly following the privatization of power supplies. Complaints involved misleading consumers about potential savings and, in some cases, forging the signatures of consumers in contracts to change suppliers ${ }^{15}$.

\section{Doorstep sales:}

These sales tactics often take the form of doorstep selling, long regarded as a problem affecting consumers [20,22]. Investigations by the British OFT have revealed sales techniques such as aggressive marketing or pressure selling. Well trained salesmen, they comment, can exploit consumers, many of whom are unaware of their rights [58].

These examples, while not providing systematic estimates of the total volume of crime involving consumer victims, do indicate its universal and everyday nature. Many more could be added. Time and space prohibits, for example, issues of water and other drinks such as wine, the sale of 'bogus' health products often known as 'quackery', the misleading tactics used by travel companies in selling holidays and the scope of this paper also excludes financial services and credit.

Consumers are therefore harmed by a plethora of offences although focusing on the impact on all consumers can mask their unequal impact on specific groups. Products and services are often, for example, specifically marketed at particular groups and some groups may be more economically or physically vulnerable to particular effects. Consumers also vary in the extent to which they are aware of the risks of specific items or are able to avoid harm. It is useful to ask therefore, which crimes affect which groups of consumers. In exploring this question it is important to recognize that relationships are far from clear cut. While stereotypes might suggest for example that 'little old ladies' [19] or 'Aunt Agathas' [46] are particularly

\footnotetext{
${ }^{13}$ [5] cited in [20]

${ }^{14}$ Institute of Trading Standards Press release 27/11/2001 cited in [22]

${ }^{15}$ Energywatch Press Release 30/01/02 and other cases cited in [22]
} 
vulnerable and popular representations play on the vulnerability of older people, generalizations must be avoided. As Titus [78] points out, people learn by experience and older consumers may be more aware of risks, while younger consumers may be more prepared to take them. Socio economic status and education will also affect how well informed consumers are. Thus factors such as age, gender and socio economic status, explored in the following sections, are interrelated.

\section{Gender}

While many areas of women's victimization have been extensively researched, the study of white-collar and corporate crime has been characterized as 'gender blind' [74]. Some feminist scholars have however pointed to the way in which many of the major 'mass harms' associated with the pharmaceutical industry, such as the case of the Dalkon Shield contraceptive [33] and silicon breast implants have affected women [61] and have been related to (men's) desires to change or alter women's bodies. This section will explore the extent to which female consumers are harmed by a range of products and services before placing this in the context of wider ideological and cultural factors.

Women can be more vulnerable to the effects of the chemicals in many consumer products either because they consume more or because they are more likely to be physically affected. While, for example, men and women consume cosmetic products, and indeed men's consumption of 'grooming products' is growing [35], women's exposure to chemicals is arguably greater. Lipstick is licked, eye shadow and mascara can be absorbed by mucous membranes and it has been estimated that in Britain most women absorb around $2 \mathrm{~kg}$ of chemicals through cosmetic products every year [92, 94] and can use up to 20 different products as part of their daily routine [93]. Hair dyes have been linked to bladder cancer in women particularly in hairdressers [36, 92].

Similarly, while men and women both undergo cosmetic treatments and surgery, women tend be the major consumers. In Britain, for example, there has been a rise, to 2004, in all the major areas of beauty treatment such as breast augmentation (which costs around £5,750), eyelid surgery, liposuction, face and neck lifts and ear pinning [49]. A number of high profile women have been harmed. A well known footballer's wife almost died after her bowel was perforated during a 'tummy tuck' and she suffered severe septicaemia, renal failure, cardiac arrest and a collapsed lung [40]. A well known actress suffered embarrassing publicity when, following lip injections, she suffered a reaction causing her lips to swell and required painful corrective treatment and a model had to give up her career following her nose being reduced to a 'shapeless nub' [25].

A range of other products have health implications. Domestic cleaning products have been associated with skin problems and allergic reactions and the large numbers of chemicals which they contain particularly affect women who stay at home [73]. Indeed it has been suggested that women who work at home have a 54\% higher rate death rate from cancer which has been related to the rise in household cleaning products and toiletries ${ }^{16}$. The so called 'diet industry' has also been

\footnotetext{
${ }^{16}$ [79] Cleaning Yourself to Death, Newleaf, Dublin cited in Hazards in the Home Factsheet no 5 available from Merseyside HAZARDS and Environmental Centre Toxteth Town Hall Liverpool
} 
associated with many adverse side effects. In the US, it was associated with 35 deaths during the 1970s and 1980s and in Britain, diets have been associated with gallstones, constipation, heart stress, infertility and depression [13, 19]. As seen above, many so called 'low fat' products may be no less 'fattening' than other products. As the majority of diets do not work, their widespread marketing could also be said to involve misleading descriptions. While it could be argued that men also diet, cultural pressures arguably affect women more [13, 19, 22].

Stereotypically women are often assumed to be more vulnerable to fraud and particularly to fraud on the part of garages, although there has been little evidence to support this assumption [67]. The previously mentioned DTI mystery shopping survey did find some differences. Garages missed at least one item in the service schedule for $58 \%$ female compared to $40 \%$ of male owners and, while there was no difference in recommendations for unnecessary work, they carried out more work which had not been agreed for female owners and main dealers charged women $£ 50$ more than men for servicing [30]. Women who work at home have also been seen as targets for the high pressure sales tactics of doorstep sellers and appliance repair frauds [82] and it could further be argued that women are more vulnerable to 'cowboy' builders and second hand car dealers who might believe them to be, however erroneously, more ignorant and therefore unable to detect attempts to overcharge or suggest unnecessary work.

Against these examples suggesting women's higher risk of victimization it could be argued that men are also subject to a range of dangerous products or fraudulent sales tactics. The widespread advertising of cheap or counterfeit Viagra, or the longstanding sale of products claiming a miracle cure for baldness provide examples of male specific products. In the workplace, higher fatalities are involved in traditionally male industries such as building, and a culture of 'machismo' which could involve taking risks has been suggested as playing a part in this [20, 22]. Men's greater propensity to engage in 'risky' activities might also make them more vulnerable to some kinds of unsafe products or services. In Britain accident statistics indicate that men are more likely to killed or injured by what are described as 'inherently hazardous' products such as step ladders or scaffolding and men are more likely to be adversely affect by product fault, although it is said there is an element of 'behaviour' involved [26].

It cannot be concluded therefore that women are more likely to be victimized than men, but it can be argued that gender is a significant factor as commercial practices reflect gendered assumptions and must be seen in a broader cultural context. The sale of cosmetic products and surgery and diets reflects idealized notions of 'beauty' and slimness and can create pressure for women to live up to these norms. These are reflected in advertisements and the wide range of magazines marketed at women and in findings that, for example, around $75 \%$ of college women in the US report feeling worse about their looks after reading women's magazines [42]. As will be seen below, these pressures also affect young girls. The widespread marketing of cleaning products also plays on fears, particularly amongst women who stay at home, about hygiene or not having a spotless home ${ }^{17}$.

${ }^{17}$ Merseyside HAZARDS and Environmental centre, see note 99, Factsheet 5 Cleaning Products 
Age

Products and services are also directed at different age groups, and both physical vulnerability and economic dependency can be factors in age related victimization. The very old and the very young are seen as particularly vulnerable and victimization varies through the life cycle.

\section{Young consumer victims}

The very young, babies and infants, are physically more vulnerable to the adverse effects of chemicals in foods and consumer products. Children inhale more air than adults, and their skin is five times thinner and more permeable, therefore chemicals can more easily penetrate and have greater effects. This is particularly the case with babies who lack a blood brain barrier which makes low level exposures more damaging [3]. Baby care products are tested but some believe that tests are inadequate. One toxicopathologist for example argues that:

From the day they are conceived, our children are exposed to a soup of chemicals ....most children have measurable levels of at least 300 groups of chemicals in their bodies, taken in through food, household or garden chemicals, cosmetics and even the air they breathe... ${ }^{18}$

While the effects of this exposure are not yet known it has been linked to hormone dependent cancers and early puberty. Phthalates are found in many baby toiletries and in some 'parfums' and disposable nappies contain a variety of chemical mixtures including sodium polyacrylate, removed from tampons in 1985 because of its link to toxic shock syndrome [2].

Children are also more vulnerable to the effects of chemicals in the home. When used daily, aerosols, air fresheners, deodorants, polish and hairspray can make mothers and babies ill and lead to diarrhoea and earache [52]. Children are also the subject of aggressive advertising campaigns for food and toys. Many foods marketed for children such as the cereals or chicken nuggets mentioned above contain high levels of sugar, fat and salt. Toy safety is also a major consumer issue [21, 22, 67] with a number of toys having been banned for containing phthalates, used in pacifiers, and other harmful substances. Christmas time regularly sees a spate of safety warnings from regulators about, for example, dangerous toys and electrical decorations [21, 22].

Young people now form a growing consumer market and, in an extensive survey carried out with 1,000 young people aged between 10 and 19, the British NCC found a high awareness of brands and a strong interest in consumption [50]. Nearly half 10-12 year olds considered brand to be important and the average 10 year old has internalized 3-400 brands. As will be seen below this is more extreme for children from poorer backgrounds. In addition they found that young people felt that they were treated as second class customers by shops and companies with $70 \%$ reporting having been 'ripped off'.

\footnotetext{
${ }^{18}$ Dr Vyvyan Howard cited in [2]
} 
Mobile phone companies have been identified as particular offenders. In the US, around one fifth of 16-24 year olds were found to be dissatisfied with marketing practices such as tiny writing in contracts, different prices and over pricing [34]. One local council in Britain considered $59 \%$ of mobile phone advertisements to be 'unfair' (although they did not breach codes of practice or regulations) in that they abused the term 'free' in relation to contracts [41]. Other young customers found that they had signed up for a premium rate subscription service thinking that they had simply bought a single ring tone [91].

Young consumers suffer from a range of other practices. Their partiality for 'risky' or adventurous activities means that their safety may be threatened by dangerous practices in for example nightclubs, fairgrounds, pop concerts or sports stadia. In Britain, four teenagers were drowned while staying at a leisure centre where it was subsequently found that staff had been insufficiently trained and previous warnings about safety had been ignored [17, 22, 72]. They are also major purchasers of cheap counterfeit products such as CDs, DVDs, videos and fashion items and, while they may not see themselves as 'victims' as they have obtained cheaper goods, they risk buying goods of inferior quality [22].

The victimization of children and young people must be seen in the context of the growing market in children's goods and what the British NCC describe as the 'relentless' targeting of young consumers in a highly commercialised setting [50]. Young Britons, they estimate, constitute a market worth $£ 30$ billion, with one million 5-9 year olds owning a mobile phone, half of all 15-16 year olds having a TV in their room and expenditure on snacks, sweets, music CDs, footwear, computer software, magazines, toiletries and toys worth around $£ 2$ billion. Children experience stress as a result of marketing with girls in particular feeling pressure to have the latest items, and reporting feelings of inadequacy and discomfort as a result of advertisers' images of perfection. They cite one study linking consumer involvement in young people to depression, anxiety, low self esteem and psychosomatic complaints, identifying the cause as commercial marketing ${ }^{19}$. Another survey, carried out by the teen magazine Bliss, found that over one third of 14-15 year old girls reported feeling unhappy or miserable as a result of pressures to look good, and yet another survey found that $71.4 \%$ of 7 year old girls want to be slimmer [50].

\section{Older consumer victims}

Older people are more physically vulnerable to offences affecting health and food poisoning particularly affects older victims. In the case of E.coli poisoning 21 pensioners died as did 19 residents of an old people's home in Canada in $1985^{20}$. Physical vulnerability may also make them subject to a variety of frauds involving 'quackery', 'miracle' cures, investment frauds and selling products and services which exploit their fears and worries $[32,67]$. A section of the website of the L.A. County Attorney's office provides crime prevention advice for seniors and it lists many scams which target older people including aggressive, persuasive and

\footnotetext{
${ }^{19}$ [70] cited in [50]

20 The Guardian 20/12/96
} 
intimidating sales techniques, prize and sweepstake frauds, Pyramid and Ponzi schemes, fraudulent charities, fraudulent living trusts, door to door sales and home repair frauds. Criminals, they point out, know that seniors may be retired and at home during the day with time to talk ${ }^{21}$.

In Britain, older consumers are seen as a particularly vulnerable group [12] and a variety of 'sharp selling practices' have included the sale of 'assistive products' for older people [9], security devices and the sale of bogus burglar alarms which prey on old people's greater fear of crime. In one case described by the Office of Fair Trading (OFT), a salesman from a fire alarm company called "FIRE!!!" through the door of an elderly person, and, when the door was opened, asked how safe they would have been had it been a real fire [6]. The elderly are targeted because they are seen to be 'easy to pressure, vulnerable, at home and living alone"22.

Many press reports about 'cowboy builders' highlight their effect on the elderly. In a case in which a gang of builders had targeted old people, the sentencing Judge commented that 'the family business was devoted to fleecing elderly, vulnerable victims'. The offenders were said to have marched victims to the bank after falsely claiming their homes could collapse [60], and other reports indicate that the age and vulnerability of the victim was a factor taken account of in sentencing. It cannot be assumed from this however that older people are more likely to suffer from these offences as the press is more likely to feature the victimization of older people.

As noted above, generalizations about the vulnerability of the elderly may be overdrawn. While they are often assumed to be ignorant or gullible, Titus found that they were no more vulnerable to a range of frauds and that 'in addition to getting older, they have also gotten smarter' ([77]: 66). Press reports may exaggerate the 'vulnerability' of 'innocent' elderly victims although at the same time some argue that elderly victims are seen as less deserving as they may be seen as 'culturally legitimate victims' ([32]: 158). As is the case with gender, it cannot be said that either young or old consumers suffer more from crime - the middle aged are liable to be affected by many of the offences described above. Nonetheless, it can be argued that the victimization of older people should be placed in the context of ageist assumptions and attempts to prey on the assumed weaknesses of the elderly. Vulnerability is also strongly related to socio economic status, the next factor to be discussed.

\section{Socio economic status and victimization}

There is a complex relationship between white-collar crime victimization and social status $[20,22]$. On the one hand, as is the case for conventional crime, the more affluent present attractive targets as they have more to spend. Consumers from all status groups suffer from chemicals in cosmetics and additives in food and the more affluent pay more for overpriced and deceptively packaged luxury goods. Women who undergo cosmetic surgery or beauty treatments are also among the more affluent. On the other hand the poor are less able to avoid purchasing cheap and often substandard or dangerous goods, second hand cars and cheap, highly processed food products.

\footnotetext{
${ }^{21} \mathrm{http}: / /$ da.co.la.ca.us/seniors/crimes.htm (accessed 8/8/05)

${ }^{22}$ Office of Fair Trading Press Release 3/5/00
} 
More affluent consumers are less likely to use 'cowboy' builders and are more likely to be informed about the risks involved in foods and other consumer goods. Therefore consumers' ability to choose products and services and their ability to access information on which to base these choices are key factors affecting the risk of being harmed, which could well be associated with the concept of 'cultural capital' [20, 22].

In respect of other white-collar crimes, Shapiro points to the importance of 'asymmetries of information' between, for example, employers and employees. Employers are seen as particularly vulnerable to the offences of employees, such as accountants or computer specialists, who are employed for their expertise and whose performance is difficult to assess as employers may not possess similar expertise [71]. This is relevant to the relationship between manufacturers or sellers and consumers. While employers, argues Shapiro, can adopt 'risk abatement strategies', the less well educated consumer has less knowledge on which to recognize risk and is less able to seek advice or take action [20].

A variety of sources confirm these kinds of inequalities. The British OFT considers some groups, including the elderly, the young and those on low incomes as vulnerable consumers as they are less able to obtain or assimilate the information needed to make informed decisions and are exposed to greater 'loss of welfare' through purchasing inappropriate goods or services [12]. Research carried out for the British DTI found that one third of consumers felt poorly informed. Those in social classes A and B and higher income earners felt better informed of their rights, felt it was easy to get information and advice and had more knowledge of consumer organizations. Those in classes D and E felt least informed and had less knowledge of appropriate bodies suggesting that 'access difficulties' might hinder the knowledge of consumers in lower social classes [29].

This is underlined when considering the situation of the most disadvantaged consumers. To the British NCC, 'disadvantaged consumers' include those with a low income, living in a deprived area, recruited from first or second generation black and minority ethnic backgrounds along with people with basic skills difficulties and those with young children. In a research project they found that many in these groups lacked the skills and confidence to act as empowered consumers. Many found it difficult to access more affordable and high quality foods, particularly as many of the large supermarkets offering a range of inexpensive foods are located in out of town sites, inaccessible for those without cars. Black and ethnic minorities however had a wider range of ethnic foods and good quality raw ingredients available to them [55]. The NCC estimate that 4 million people in the UK cannot afford a healthy diet $[44,54]$ and point to the existence of food 'deserts' where those without a car are unable to find sufficient choice at prices they can afford. Thus the 'poor pay more' [55] as their choice is restricted and they cannot buy in bulk. Many of the consumers interviewed also felt that they were the targets of 'irresponsible' sales practices such as 'two for one' convenience dinners and promotions for fashionable items such as children's trainers. The NCC argues that while the complexity of the market increases choice, decisions are more difficult, and often beyond the skills of, disadvantaged consumers, thus increasing the potential for misselling [56].

Young consumers also experience these inequalities in purchasing power. The NCC survey of young people considers that advertising 'makes poverty bite' and identifies an 'aspiration gap'. Children in the poorest households were most likely to 
be brand aware, more bothered about the make of the family car and wanted clothes with popular labels. Yet however hard parents tried to satisfy these desires and to avoid the embarrassment and bullying which they feared, children expressed most dissatisfaction and discontent with family spending. Furthermore, they argue, childhood obesity, which is linked to poverty, may be exacerbated by parents compensating for lack of money by buying cheap, aggressively marketed but unhealthy food brands. They conclude that the consumer society's emphasis on clothes and consumer goods can contribute to social exclusion [50].

\section{Conclusion}

The examples cited above have necessarily been selective and other aspects of inequality could usefully be explored in more depth. Racial inequalities could be more fully investigated and there are also global inequalities as many consumer goods and food products are exported to or 'dumped' in countries with less stringent regulatory systems [67]. Other areas of consumer victimization such as financial and health services provide fruitful areas for future investigation. While selective, the foregoing analysis nonetheless strongly suggests that that the victimization of consumers by white collar and corporate crime reflects wider social inequalities.

Despite there being insufficient information to claim that any one group such as women, older people or the poor are statistically more likely to suffer harm - indeed men, the middle aged or the affluent are attractive targets - it can be argued that some groups are particularly vulnerable, through a combination of physical, economic and other factors, to products, services and sales practices whose marketing reflects wider cultural assumptions and structural inequalities. While women or older people may not be as 'gullible' or ignorant as often assumed, these cultural assumptions continue to make them more likely targets. As was also seen above, many consumerist pressures are difficult to resist as evidenced in findings that young people are intensely brand aware and that women and girls experience pressures in relation to appearance.

Gender and age factors are in turn related to socio economic status. It could be argued for example that more affluent older people, more educated women and young people with more highly informed parents might be better able to avoid victimization in contrast to the situation of poorer consumers who have less information yet face greater pressure. Cultural capital combines with structural inequalities. As seen above the poor 'pay more' as they cannot afford to buy in bulk or are restricted to shopping in more expensive outlets. They are also more likely targets of the often deceptive sales practices offering 'discount' or 'bargain' goods and services and are subject to considerable pressure to purchase goods and foods for their children which are seen as 'essential'. As is the case with other areas of criminal victimization therefore, the impact of crime falls more heavily on the most disadvantaged. It could also be argued that deregulatory pressures, which may lead to a reduction in the role of enforcement officers to investigate and prosecute offences, may exacerbate this situation as in Britain as elsewhere, current policies emphasize the role of informed, aware and empowered consumers ${ }^{23}$.

\footnotetext{
${ }^{23}$ see, for example, the DTI consultation paper, [27]
} 


\section{References}

1. Adams, L and Bannerman, L (2005) "Gas firm fined $£ 15$ million for the death of a family" The Herald 26 Aug. www.theherald.co.uk/news/45795 accessed 26/08/05.

2. Atkins and Sample (2004a) Women's Environmental Network www.wen.org.uk.

3. Atkins, L and Sample, I (2004b) "Throw out the Bath Water? They look harmless enough, but your average baby care product contains a cocktail of chemicals that might surprise you" The Guardian 8 May, p.20.

4. Aubert, V (1977) "White collar crime and social structure", in G. Geis and R.F. Maier (eds) White Collar Crime: Offences in Business, Politics and the Professions - Classic and Contemporary Views. New York: Free Press, Collier and Macmillan.

5. Automobile Association (1994) (in association with the Institute of Trading Standards Administration) Consumer Protection for Motorists: A Survey of Complaints and Proposals for Action. London: AA, June 1994.

6. Bannister, N (2000) "Byers targets rogue traders" Guardian Unlimited 2/12/2000.

7. Barton, L and Branigan, T (2004) "Chemical World: LIP SERVICE: Makers of cosmetics and toiletries police the safety of their own products. That's not good enough", The Guardian 8th. May, p. 27.

8. Beatty, S (2004) "FDA's Crackdown Adds a Wrinkle to Marketing of Anti aging Skin Treatments" Wall Street Journal (Eastern Edition).15 Mar., p. B.1.

9. Biswell, K (2004) “Consumers and standards: increasing influence," 14 Consumer Policy Review $177-185$.

10. Blake, A (2004) “300,000 homeowners 'ripped off”" Western Mail. Cardiff 23 Apr., p. 3.

11. Boseley, S (2005) "Cosmetic injections may carry CJD risk” The Guardian 29 Jan., p.13.

12. Burden, R (1998) Vulnerable consumer groups: quantification and analysis. Research Paper No. 15, prepared for the Office of Fair Trading, London: Office of Fair Trading.

13. Claybrook, J (1996) "Women in the Marketplace", in E. Szockyj \& J.G. Fox (eds) Corporate Victimisation of Women. Boston, Mass: Northeastern University Press.

14. Clinard, M \& Yeager, P (1980) Corporate Crime New York: Free Press.

15. Croall, H (1988) "Mistakes, accidents and someone else's fault: the trading offender in court", 15 Journal of Law and Society, 293-315.

16. Croall, H (1989) "Who is the White Collar Criminal?" 29 British Journal of Criminology 157-74.

17. Croall, H (1998) "Business, Crime and the Community", 3 International Journal of Risk, Security and Crime Prevention 281-92.

18. Croall, H (1999) "Crime, Business and Community Safety", 5 Scottish Journal of Criminal Justice Studies, 65-81.

19. Croall, H (1995) 'Target Women: Women's victimization from white collar crime', in R. Dobash and L. Noaks (eds) Gender and Crime. Cardiff: Cardiff University Press.

20. Croall, H (2001a) Understanding White Collar Crime. Buckingham: Open University Press.

21. Croall, H (2001b) "The Victims of White Collar Crime" in Lindgren Sven-Ake (ed) White-Collar crime Research. Old Views and Future Potentials: Lectures and Papers from a Scandinavian Seminar National Council for Crime Prevention, Sweden Bra-Report 2001:1.

22. Croall, H (2004) "Cheated and Poisoned: Exposing the victims of economic crime" Report for Swedish Council of Crime Prevention (BRA) Stockholm.

23. Croall, H (2005) "Following the food chain of crime" unpublished paper delivered to the annual British Criminology Conference, University of Leeds, July.

24. Croall, H and Ross, J (2002) "Sentencing the Corporate Offender: Legal and Social Issues" in N. Hutton \& C. Tata, Sentencing and Society Aldershot: Ashgate.

25. Daily Mail (2005) 'Health chiefs crack down on the cosmetic cowboys' Daily Mail Jan 29, 2005. p. 13.

26. Department of Trade and Industry (2005) "Home Accidents involving product fault or contributory behaviour" www.dti.gov.uk/homesafetynetwork/gh_rsrch.htm accessed July 2005.

27. Department of Trade and Industry (2004) "Extending Competitive Markets: Empowered Consumers, Competitive Businesses" Consultation Paper London: Department of Trade and Industry, July.

28. Department of Trade and Industry (2003) "Comparative Report on Consumer Policy Regimes" London: Department of Trade and Industry, October.

29. Department of Trade and Industry (2001) "Consumer Knowledge Performance Monitor" Consumer Affairs report series No.4 London: Department of Trade and Industry. 
30. Department of Trade and Industry (2002) "Car Servicing and Repairs: Mystery Shopping research" September, London: Department of Trade and Industry.

31. Eleanor Hughes (1994) 'Key note report, Cosmetics and Fragrances - A market sector overview 10th. Edition' cited in WEN fact sheet on cosmetics available at www.wen.org.uk/cosmetics/facts.htm, accessed July 2005.

32. Fattah, E \& Sacco, V (1989) Crime and Victimization of the Elderly. New York: Springer Verlag.

33. Finlay, L (1996) "The Pharmaceutical Industry and Women's Reproductive Health", in E. Szockyj \& J.G. Fox (eds) Corporate Victimisation of Women. Boston: Northeastern University Press.

34. Foley, RJ (2003) "Consumer Complaints Soared in 2002" Wall Street Journal, November 25.

35. Foster, L (2004) "Moisturiser maketh the man: Consumer products groups are scrambling to cash in on a radical change in men's attitudes to grooming" Financial Times, August 16.

36. Fletcher, V (2003) "Hair dye alert as study reveals risks to health; Makers accused of insufficient testing” Evening Standard London 22 Apr., p. 15.

37. Geis, G \& Edelhertz, H (1973) "Criminal Law and Consumer Fraud: a socio-legal view" 2 American Criminal Law Review, 989-1010.

38. Gould, N (2005) "Ulster doctor warns of maverick cosmetics practitioners; Beware the Botox cowboys" Belfast Telegraph 14 Jun., p. 1.

39. Hall, C (2005) "Health crackdown on beauty clinics and Botox parties" The Daily Telegraph 29 Jan., p. 05 .

40. Hayward, S (2003) "New Checks on Cowboy Clinics" Sunday Mirror London: Jul 13, p. 39.

41. Heath, A (2005) "Young victims of the mobile phone adverts" Coventry Evening Telegraph 4 Mar., p. 10 .

42. Kilbourne, J (1999) Deadly Persuasion cited on www.wen.org.uk/cosmetics/facts.htm accessed 27/07/05.

43. Laurance, J (2002) "1 in 10 plastic surgeons 'offer needless treatment" The Independent 8 Oct., p. 8.

44. Lawrence, F (2004a) Not on the Label! What really goes into the Food on your Plate London: Penguin Books.

45. Lawrence, F (2004b) 'Supermarkets criticised over water in fresh pork' The Guardian 16 July.

46. Levi, M (1999) The Impact of Fraud, Criminal Justice Matters, 36 (summer).

47. Lindgren S (2002) "Economic crime in Sweden: An essentially contested Issue" 2 Criminal Justice, $363-383$.

48. Lister, S (2005a) 'Secrets and lies of beauty industry laid bare by advertising watchdog' The Times, 11 May.

49. Lister, S (2005b) 'Tighter facelift rules will tackle rogue practitioners' The Times 28 Jan., p. 11.

50. Mayo, E (2005) 'Shopping Generation.' London: National Consumer Council.

51. Millstone, E and Lang, T (2003) The Atlas of Food. Earthscan Books.

52. Morton, E (2004) "Aerosols "making tots sick" The Sun 19 Oct., p. 18.

53. National Consumer Council (2004) Car repairs and servicing: Key facts Fact Sheet, April. London: National Consumer Council.

54. National Consumer Council (2005) "Putting food access on the radar: how to target and prioritise communities at risk" London: National Consumer Council.

55. National Consumer Council (2003) "Everyday essentials: meeting basic needs. Research into accessing essential goods and services" London: National Consumer Council, Jan. 2003.

56. National Consumer Council 'Poor pay more' information pack available on www.ncc.org.uk.

57. Nelken, D (2002) 'White Collar Crime' in Maguire, M., Morgan, R. \& Reiner, R. (eds) The Oxford Handbook of Criminology, 3rd edition, Oxford: Oxford University Press.

58. Office of Fair Trading (2004) Report on 'Pressure Sales', 12 May 2004 www.oft.gov.uk accessed September 2004.

59. Peake, A (2004) "Cowboy builders take us for £1BN" The Sun London 19 Oct., p.15.

60. Penrose, J (2003) "Cowboys jailed over Pounds 1m scam on elderly” The Sun London 25 Oct., p. 23.

61. Peppin, J (1995) Feminism, Law and the Pharmaceutical Industry, in F. Pearce \& L. Snider (eds) Corporate Crime: Contemporary Debates. Toronto: University of Toronto Press.

62. Powell, D (2005) "The posse; Riding out to beat cowboy builders" Daily Post Liverpool 20 May, p. 2.

63. Product Safety-Problem Solved? PS-Not? (2005) www.rospa.com/productsafety/articles/problem solved.htm accessed July 2005.

64. Prynn, J (2004) 'Exposed: rip-offs of cowboy Workmen” Evening Standard London 22 Jan., p. 1.

65. Punch, M (1996) Dirty Business: Exploring Corporate Misconduct. London: Sage.

66. Rahman, B (2003) 'Sentences outrage consumer groups JAPAN POISONING CASE' Financial times 28 May. 
67. Rosoff, S, Pontell, H and Tillman, R (1998) Profit without Honor: White Collar Crime and the Looting of America New Jersey: Prentice Hall.

68. Ruggiero, V. (1996) Organized and Corporate Crime in Europe: Offers that can't be refused. Aldershot: Dartmouth.

69. Rowan, D and Kellow, J (2004) "Pack of porky pies" The Times 20 Mar, p. 16.

70. Schor, J (2004) "Born to Buy: The commercialised child and the New Consumer culture" Scribner.

71. Shapiro, S (1990) "Collaring the crime, not the criminal: re-considering the concept of white collar crime", 55 American Sociological Review, 346-65.

72. Slapper, G and Tombs, S (1999) Corporate Crime. London: Addison Wesley Longman.

73. Simpson, S and Elis, L (1996) 'Theoretical Perspectives on the corporate victimization of women', in E. Szockyj and J.G. Fox (eds) Corporate Victimisation of Women. Boston, Mass: Northeastern University Press.

74. Snider, L (1996) 'Directions for Social Change and Political Action' in E. Szockyj \& J.G. Fox (eds) Corporate Victimisation of Women. Boston, Mass: Northeastern University Press.

75. Stringer D (2003) 'Maggot Pete' gets six years for food fraud' The Independent 13 Dec., p. 13.

76. Sutherland, E (1949) White Collar Crime New York: Holt, Reinhart \& Winston.

77. Titus, RM, Heinzelman, F and Boyle, JM (1995) 'Victimization of Persons by Fraud' Crime and Delinquency vol 41.

78. Titus, R.M. (2001) 'Personal Fraud and its Victims' in Shover N \& Wright J P (eds) Crimes of Privilege: Readings in White-Collar Crime. New York and Oxford: Oxford University Press.

79. Thomas, P (2001) Cleaning Yourself to Death. Newleaf, Dublin.

80. Uhlig, R (2004) "Farmhouse fresh? It's more likely to have been produced on an industrial estate Government watchdog accuses supermarkets and manufacturers of duping shoppers with misleading labels" The Daily Telegraph 12 Feb., p 04.

81. Utton, T (2004) "It may say organic, but it could be GM; Misleading labels blamed for not warning of polluted soya: Daily Mail campaign Frankenstein food watch” Daily Mail 11 Mar., p. 15.

82. Vaughan, D and Carlo, G (1975) "The appliance repairman: a study of victim-responsiveness and fraud”, 12 Journal of Research in crime and Delinquency, 153-61.

83. Which? (2002) 'Food Labelling' Which? Online Dec 2002.

84. Which? (2004a) 'Food Safety' Which? Online Feb 2004.

85. Which? (2004b) 'No to GM' Which? Online Sep 2004.

86. Which? (2004d) 'Cereal Offenders' Which? Online April 2004.

87. Which? (2004e) 'Trick packs? Which? Online Nov 2004.

88. Which? (2004f) Products Recalls: A burning issue Which? Online March 2004.

89. Which? (2005a) 'Nutrition labelling' Which? Online March 2005.

90. Which? (2005b) 'Food Packaging' Which? Online April 2005.

91. Whiteside, P (2005) "The Danes and Germans have cracked down on ring tone rip-offs ... why can't we?; Britain's mobile phone giants accused of hypocrisy" Mail on Sunday 8 May, p. 43.

92. Women's Environmental Network (WEN) www.wen.org.uk

93. Women's Environmental Network (2005) www.wen.org.uk/cosmetics/facts.htm accessed 27/07/05.

94. Woods (2005a) Women's Environmental Network (WEN) www.wen.org.uk accessed July 2004.

95. Woods, J (2005b) "Is make-up making you sick? Britain’s $£ 6$ billion cosmetics and toiletries industry is facing calls to tighten up safeguards on its chemical ingredients. Just how safe are our lipsticks and moisturisers, asks Judith Woods' The Daily Telegraph 18 Mar., p 022. 